\title{
Co-occurrence of human papillomavirus (HPV) in newborns and their parents
}

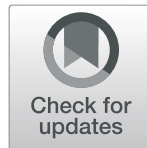

Mariusz Skoczyński ${ }^{*}$ DD, Anna Goździcka-Józefiak² and Anna Kwaśniewska

\begin{abstract}
Background: The potential HPV transmission route includes horizontal transmission "in utero" and vertical transmission from parents. Less is known about the role of child's father as a potential source of HPV infection and involved in the pathogen's epidemic chain. A possible consequence of perinatal infection includes HPV-related childhood diseases and carrying the risk of cervical cancer development in female offspring. In view of the evidence, studies of HPV co-occurrence in one or both parents and their offspring seem vital for the implementation of respective preventive measures. Consequently, the aim of this study was to determine the incidence of common HPV 16/18 infections in newborns and their parents, and to assess its role of the periconceptional transmission.

Methods: To determine the incidence of common HPV infections in newborns from single pregnancies and their parents. The study included 146 pregnant women, as well as their partners, and newborns. They were tested for the presence of HPV 16/18 DNA using the PCR method. HPV types 16 and/or 18 were identified using type-specific PCR primers. The quality of the extracted DNA was evaluated by PCR using PC03/PC04 $\beta$-globin-specific primers. The relationship between the presence of neonatal and parental HPV infection was analyzed using a multivariable regression model. Calculations were carried out with the Statistica 10.

Results: The presence of HPV DNA was detected in 19 (13,01\%) newborns, 28 (19,18\%) mothers, and 20 (13,7\%) fathers. The viral DNA was detected in 14 newborns delivered by HPV-positive mothers (OR=26,08; Cl: 8,07-84,31, $p<$ $0.001), 12$ descendants of HPV-positive fathers ( $\mathrm{OR}=22,13 ; \mathrm{Cl}: 6,97-70,27, p<0.001)$, and 10 children originating from two infected parents ( $\mathrm{OR}=24,20 ; \mathrm{Cl}: 6,84-85,57 p<0.001)$. Those findings points to a increase risk of an acquired infection in newborns with HPV-positive parents.
\end{abstract}

Conclusion: Our findings suggest the possible role of the periconceptional transmission in the mode of acquired HPV 16/18 infections.

Keywords: Maternal infection, Paternal infection, Periconceptional infection, Perinatal transmission

\section{Background}

The potential HPV transmission route includes horizontal transmission "in utero" and vertical transmission from parents. Data presented in various researches show the possibility of perinatal or intrauterine mode of infection [1-4]. Less is known about the role of child's father as a potential source of HPV infection, although it was revealed that men are involved in the pathogen's epidemic chain [4-6]. Several authors confirmed the presence of HPV in semen, which raises the possibility of periconceptional infection [6, 7]. Consequently, this route of

\footnotetext{
* Correspondence: mskoczynski@wp.pl

${ }^{1}$ Department of Obstetrics and Pathology of Pregnancy, Medical University of Lublin, Lublin, Poland

Full list of author information is available at the end of the article
}

transmission is postulated to be a potential reason of a persistent viral infection of the child [6,7]. A possible consequence of perinatal infection includes HPV-related childhood diseases and carrying the risk of cervical cancer development in female offspring $[4,8,9]$. In view of the aforementioned evidence, studies of HPV co-occurrence in one or both parents and their offspring seem vital in order to understand the pathogenesis of pregnancyrelated infections with this pathogen as well as for the implementation of respective preventive measures. Consequently, the aim of this study was to determine the incidence of common HPV types 16 and/or 18 infections in newborns and their parents, and to assess the role of the periconceptional transmission. 


\section{Methods}

\section{Patients}

This research was conducted between March 2009 and July 2011. The studied group comprised pregnant women who delivered at the Clinic of Obstetrics and Pathology of Pregnancy, Medical University of Lublin (Poland), and their partners. For the study we recruited 146 consecutive parental couples. The gestational age varied from 33 to 41 weeks. Individuals selected for this study met specific inclusion criteria. Among those criteria were: 1) singleton pregnancy, 2) no HPV infection symptoms present in any of the parents, and 3) physiological cervical smear in pregnant woman. Among the exclusion criteria were: 1) previous HPV infections, 2) abnormal cervical smear in pregnant woman, and 3) multiple pregnancy.

The protocol of this study was performed in accordance with the Declaration of Helsinki and approved by Local Bioethical Committee at the Medical University of Lublin (No. KE-0254/143/2007). Before participation in any of the procedures the studied group expressed their consent by completing a written form.

\section{Samples}

Posterior vaginal fornix smear samples as well as peripheral blood samples were collected from the women in the onset of labour. Additionally, buccal mucosal smears were drawn from both parents and their children. Discharge gathered in newborns upper airways was extracted in order for buccal smears to be collected directly after birth. A suitably trained member of the personnel managed the collection of all material. Subsequently the samples were transferred to sterile tubes awaiting for HPV DNA testing (Eurotubo; Deltalab, Spain). The material was then subject to freezing at $70{ }^{\circ} \mathrm{C}$ pending additional analyses.

\section{PCR identification}

PCR testing was utilized as means of detecting HPV DNA in the collected samples. HPV types distinction was made possible by using PCR primers for L1: MY09: 5'-CGTC CMARRGGAWACTGATC-3' and MY11: 5' -GCMCAAG GWCATAAYAATGG-3', where $\mathrm{M}=\mathrm{A}+\mathrm{C}, \mathrm{R}=\mathrm{A}+\mathrm{G}$, $\mathrm{W}=\mathrm{A}+\mathrm{T}, \mathrm{Y}=\mathrm{C}+\mathrm{T}$. This set of primers amplifies DNA from at least 33 different HPV genotypes. HPV types 16 and/or 18 were identified using the following type-specific PCR primers: HPV16/L1A/HPV16/L1B, 5'-GCCTGT GTAGGTGTTGAGGT-3' and 5'-TGGATTTACTCCAA CATTGG-3' product size: 264 bp; HPV18/L1A/ HPV18/ L1B, 5-' GTGGACCAGCAAATACAGGA-3'and 5' - TG CAACGACCACGTGTTGGA-3', product size: $162 \mathrm{bp}$; HPV18ME12/HPV18ME50/E6, 5'-CACGGCGACCCTAC AAGCTACCTG-3', and 5' -TGCAGCACGAATTGGCAC TGGCCTC-3', product size: $404 \mathrm{bp}$. The quality of the extracted DNA was evaluated by PCR using PC03/PC04 $\beta$ - globin-specific primers. The reaction described above was developed with reference according to Tucker et al. [10]. The total volume of $10 \mu \mathrm{l}$ of PCR mixture contained $1 \mu \mathrm{M}$ of primers, $200 \mu \mathrm{M}$ of deoxynucleotide triphosphates, $1 \mathrm{x}$ PCR buffer (0.1 M Tris- $\mathrm{HCl} \mathrm{pH} \mathrm{8.8,} 0.5 \mathrm{M} \mathrm{KCl}, 0.015 \mathrm{M}$ $\mathrm{MgCl}_{2}, 1 \%$ Triton X-100), the investigated DNA (10 ng/ $\left.\mu \mathrm{l}\right)$, and Tag polymerase at a final concentration of $40 \mathrm{U} / \mathrm{ml}$. After preliminary denaturation $\left(15 \mathrm{~min}\right.$ at $\left.94{ }^{\circ} \mathrm{C}\right)$, samples were amplified for 31 cycles in a thermal cycler, consisted of a $30 \mathrm{~s}$ period of denaturation at $94{ }^{\circ} \mathrm{C}$, annealing at $59^{\circ} \mathrm{C}$ for the same amount of time, followed by primer extension at $72{ }^{\circ} \mathrm{C}$ for 1 minute. In the last PCR cycle, the stage of complementary DNA synthesis at $72{ }^{\circ} \mathrm{C}$ was extended to $420 \mathrm{~s}$. Agarose gel electrophoresis in the presence of pBluescript DNA digested with HindI was utilized to analyze PCR products. A further HPV DNA detection, and HPV genotypes identification by direct sequencing from PCR reaction tube (without purification from MY09 and MY11 oligonucleotides was performed). The obtained results were subsequently analyzed with BLAST database (http://blast.ncbi.nlm.nih.gov).

\section{Statistical methods}

To verify the normal distribution of continuous variables we use the Kolmogorov-Smirnoff test. Statistical characteristics of these variables were presented as medians and ranges, and their intergroup comparisons were performed using the Mann-Whitney U-test. The distributions of qualitative variables were compared amongst studied groups with the Pearson's chi-square test and Fischer's exact test. We use a multivariable regression model to analyze the relationship between the presence of neonatal and parental HPV infection; odds ratios (ORs) were determined. All calculations were carried out with Statistica 10 (StatSoft ${ }^{\oplus}$, Tulsa OK, USA) package, with the level of significance set at " $p \leq 0.05$.

\section{Results}

The examined group consisted of women ages 17 to 43 with a median age of 29. Twenty-eight (19.18\%) cases of HPV 16/18 infection were detected amongst the pregnant women participating in this study. In 10 cases, HPV DNA was detected solely in vaginal smears, and in 5 cases solely in the buccal smears; 13 women tested positive for both samples. In two cases, HPV DNA was also detected in the peripheral blood of the pregnant women. There was no significant difference between participants with positive and negative results on HPV DNA testing as regards their demographical and obstetrical features (Table 1).

Twenty (13.7\%) cases of HPV 16/18 infection were detected amongst fathers participating in this study as confirmed by the examination of buccal smears. The offspring of study participants included 80 female and 66 male newborns. Neonatal birth weight ranged from 
Table 1 Demographic and obstetrical characteristics of HPV types16 and/or 18-positive, and HPV types 16 and/or 18-negative pregnant women

\begin{tabular}{llll}
\hline Parameter & HPV16/18 (+) & HPV16/18 (-) & $p$ value \\
& $n=28(19.18 \%)$ & $n=118(80.82 \%)$ & 0.992 \\
Age (years) & $28.5 \pm 4.7$ & $29.38 \pm 4.59$ & $104(88.1 \%)$ \\
Marriage & $23(82.1 \%)$ & $14(11.86 \%)$ & 0.397 \\
Unmarried partnership & $5(17.86 \%)$ & $4(3.39 \%)$ & 0.397 \\
$<10$ years of education & $2(7.14 \%)$ & $7(5.93 \%)$ & 0.375 \\
Cigarette smoking & $2(7.14 \%)$ & $19.65 \pm 2.78$ & 0.812 \\
Age of sexual initiation (years) & $19.49 \pm 2.77$ & $32(27.12 \%)$ & 0.785 \\
At least three sexual partners & $8(28.57 \%)$ & $66(55.93 \%)$ & 0.873 \\
Contraceptive use & $13(46.43 \%)$ & $1.94 \pm 0.97$ & 0.365 \\
Number of pregnancies & $1.98 \pm 1.032(1-5)$ & 0.847
\end{tabular}

$n$ Number of participants

$1740 \mathrm{~g}$. to $4670 \mathrm{~g}$. with a median weight of $3405 \mathrm{~g}$. In case of 19 (13.01\%) newborns HPV 16/18 DNA was found in the collected samples. In 6 cases the infection was confirmed based on a buccal smear test and in 3 patients through examination of the upper respiratory airway discharge; 10 newborns had positive results of both samples. In one case, HPV was also detected in the umbilical blood sample. Newborns positive and those negative for HPV 16/18 DNA did not differ significantly in terms of their obstetrical characteristics (Table 2).

In the case of 15 of the $28 \mathrm{HPV}$ 16/18-positive women, the virus' genetic material was also isolated in their spouses. The presence of HPV 16/18 DNA was detected in 14 of the 28 newborns delivered by mothers in whom an HPV infection was confirmed based on the examination of at least one biological sample, in 12 of the 20 descendants of HPV 16/18 -positive fathers, and in 10 of the 15 children originating from two infected parents. The following variables (in descending order of risk) proved to be significant risk factors for the acquiring of a neonatal HPV infection on the multivariate analysis of logistic regression:
1) maternal infection confirmed by a positive result of at least one examined sample $(\mathrm{OR}=26.08$; CI:8.07-84.31, $p<0.001), 2)$ infection of both parents $(\mathrm{OR}=24.2$; CI: 6.84-85.57, $p<0.001), 3$ ) maternal infection confirmed by a positive vaginal smear test $(\mathrm{OR}=21.54$; CI:6.94-66.87, $p<0.001$ ), and 4) maternal infection confirmed by a positive buccal smear test $(\mathrm{OR}=10.64$; CI:3.47-32.63, $p<$ 0.001 ). In contrast, the risk of neonatal infection was not modulated by the detection of HPV DNA in maternal blood (OR $=6.58$; CI:0.39-112.31, $p=0.191$ ) and by the number of HPV-positive maternal samples $(\mathrm{OR}=0.98$; $\mathrm{CI}$ : 0.21-4.68, $p=0.979$ ) (Table 3).

\section{Discussion}

Recently, the possibility of perinatal transmission of HPV infection has been postulated [1, 2, 11]. In this study, we confirmed the presence of HPV 16/18 DNA in nearly $20 \%$ of examined women. Rintala M.A. and BrunMicaleff E. reported closely resembling results in terms of prevalence of HPV infection in pregnant women [12, 13]. Nonetheless the prevalence rate of HPV detection

Table 2 Obstetrical characteristics of HPV types16 and/or 18-positive and HPV types16 and/or 18-negative neonates

\begin{tabular}{|c|c|c|c|}
\hline Parameter & $\begin{array}{l}\text { HPV 16/18(+) } \\
n=19(13.01 \%)\end{array}$ & $\begin{array}{l}\text { HPV 16/18(-) } \\
n=127(86.99 \%)\end{array}$ & $p$ value \\
\hline \multicolumn{4}{|l|}{ Obstetrical characteristics } \\
\hline Gestational age (weeks) & $38.90 \pm 2.08$ & $38.12 \pm 1.69$ & 0.609 \\
\hline Cesarean section & $9(47.37 \%)$ & 79 (62.2\%) & 0.219 \\
\hline Vaginal delivery & $10(52.63 \%)$ & $48(37.8 \%)$ & 0.219 \\
\hline Rupture of membranes $>2 \mathrm{~h}$ & $6(31.58 \%)$ & $25(19.69 \%)$ & 0.237 \\
\hline Rupture of membranes $\leq 2 \mathrm{~h}$ & $13(68.42 \%)$ & $102(80.31 \%)$ & 0.237 \\
\hline \multicolumn{4}{|l|}{ Neonatal characteristics } \\
\hline Female gender & $11(57.89 \%)$ & 69 (54.33\&) & 0.769 \\
\hline Male gender & $8(42.11 \%)$ & $58(45.67 \%)$ & 0.769 \\
\hline Birth weight (g) & $3261.03 \pm 562.94$ & $3413.12 \pm 575.05$ & 0.283 \\
\hline
\end{tabular}

$n$ Number of participants 
Table 3 Odds ratio (OR) of detecting HPV 16/18 genetic material in studied neonates depending on the characteristics of HPV $16 / 18$ infection in their parents

\begin{tabular}{llll}
\hline Variable & OR & $95 \% \mathrm{Cl}$ & $p$ value \\
\hline Maternal infection - any sample & 26.08 & $8.07-84.31$ & 0.000 \\
Infection of both parents & 24.20 & $6.84-85.57$ & 0.000 \\
Paternal infection & 22.13 & $6.97-70.27$ & 0.000 \\
Maternal infection - vaginal smear & 21.54 & $6.94-66.87$ & 0.000 \\
Maternal infection - buccal smear & 10.64 & $3.47-32.63$ & 0.000 \\
Maternal infection - peripheral blood & 6.58 & $0.39-112.31$ & 0.191 \\
Number of positive maternal samples & 0.98 & $0.21-4.68$ & 0.979 \\
\hline
\end{tabular}

may vary from $5,5 \%$ up to $65 \%$, as shown by a metanalysis of 9 different studies conducted on a collective number of 2111 of pregnant women [1].

These differences can result from several causes. The main being: inhomogeneous selection standards of the study material, a diversity of methods for HPV DNA detection and relatively small quantity of the study samples [14]. False negative results may be caused by insufficient number of viral copies in the studied samples [15]. Another reason of false positive results could be a secondary contamination of the collected samples. Irrespective of this, the most frequent type of HPV isolated in pregnant women and their offspring is the highly oncogenic HPV $16[9,16]$.

Our study revealed a $13 \%$ prevalence of neonatal HPV $16 / 18$ infection, like to that observed in Bandyopadhyaya's et al. - a study including a similar amount of pregnant women and comparable techniques as in our group [17]. It has been postulated that the offspring of HPV infected mother have an increased risk of infection $[9,12,18]$. The reported frequency of HPV infection acquired during perinatal period is still highly ambiguous. Other sources claim that HPV DNA is isolated in between 1 to $18 \%$ of newborns delivered by HPV-positive mothers without clinical signs of infection $[2,19,20]$. Women with clinical symptoms of the infection bear higher risk of their children being infected i.e. between 4 and 79\% [21]. The presence of HPV types 16 and/or 18 in our study group was detected in 14 out of 28 newborns delivered by HPV 16/18- positive mothers without clinical symptoms of infection. This finding points to a significant risk of an acquired infection in newborns with HPV-positive mothers. Moreover, the statistical results of logistic regression $(\mathrm{OR}=26.08)$, also support this fact. Furthermore, our study revealed the presence of HPV types 16 and/or 18 genetic material in $13.7 \%$ of paternal buccal smears. In as many as 12 out of 20 cases, a paternal infection corresponded to the presence of HPV 16/18 DNA in newborns. We have found only a few published reports on the co-occurrence of HPV infection in men and their offspring $[7,22,23]$. Rintala et al. revealed that a parental HPV infection is associated with a $11 \%$ probability of an acquired neonatal infection [12]. The marked difference between this value and the respective rate observed in our study could result from the aforementioned differences in the research methodology. Nonetheless, the high risk of acquired infection in the offspring of HPV-positive fathers $(\mathrm{OR}=22.13)$ documented in this study substantiates further research in this matter. Our findings suggest that the presence of HPV genetic material in the father modulates the risk of neonatal infection to a similar extent as a maternal infection; it seems obvious when the sexual route of Human Papillomavirus transmission is taken into consideration. The transmission of HPV from previous intimate partners as well as the presence of an acquired infection in the mother could explain slightly lower odds ratio values of a paternal infection as compared to ORs of a maternal infection.

In more than half of the HPV-positive cases (15/28), an infection in the mother co-existed with that of the father, and in nearly $70 \%$ of cases the infection of both parents corresponded to the presence of HPV genetic material in neonatal tissues. These findings and that of the logistic regression analysis $(\mathrm{OR}=24.20)$ point to the possible role of the periconceptional transmission of the pathogen in the pathogenesis of acquired HPV infections. This substantiates further research in this direction, as well as the consideration of HPV testing of both future parents in the protocol of preconception care.

Aside from this important conclusion, our findings suggest that testing vaginal or buccal smears in pregnant women $(\mathrm{OR}=21.54$ and $\mathrm{OR}=10.64$, respectively; $p=$ 0.000 in either case) can be more useful for the risk assessment of intrauterine HPV transmission than the virology examination of peripheral blood $(\mathrm{OR}=6.58, p=$ 0.191). This finding seems particularly attractive in the context of the popularization of non-invasive methods of virology diagnosis. The identification of parents in whose swabs of the oral mucosa HPV DNA was detected can help emerge a group of children who run a relatively significant risk of being infected.

\section{Conclusion}

Our findings suggest the possible role of the periconceptional transmission in the mode of acquired HPV 16/18 infections.

\section{Abbreviations}

HPV: Human Papillomavirus; OR: Odds ratio; PCR: Polymerase Chain Reaction

\section{Acknowledgements}

Not applicable.

\section{Authors' contributions}

MS designed the concept of the study, performed the specimen collection results analyzes, drafter the manuscript, AG-J conducted DNA isolation and amplification, data analysis after sequencing, AK project coordination. All authors read and approved the final manuscript. 


\section{Funding}

This work was supported by Fund Grant KBN No. N N407016135 provided by the Polish Ministry of Science and Higher Education.

\section{Availability of data and materials}

The datasets used and/or analyzed during the current study are available from the corresponding author on reasonable request. Main data generated or analyzed during this study are included in this published article [and its supplementary information files].

\section{Ethics approval and consent to participate}

The protocol of this study was performed in accordance with the Declaration of Helsinki and approved by Local Bioethical Committee at the Medical University of Lublin (No. KE-0254/143/2007). The subjects gave their written informed consent prior to any procedure. Authors gained informed consent for publication of the dataset from participants at the point of recruitment to the trial.

\section{Consent for publication}

Not applicable.

\section{Competing interests}

The authors declare that they have no competing interests.

\section{Author details}

'Department of Obstetrics and Pathology of Pregnancy, Medical University of Lublin, Lublin, Poland. Department of Molecular Virology, Institute of Experimental Biology, Adam Mickiewicz University, Poznan, Poland.

\section{Received: 21 February 2019 Accepted: 24 September 2019}

Published online: 04 November 2019

\section{References}

1. Medeiros LR, Ethur AB, Hilgert JB, Zanini RR, Berwanger O, Bozzetti MC, et al. Vertical transmission of the human papillomavirus: a systematic quantitative review. Cad Saude Publica. 2005;21:1006-15.

2. Rombaldi RL, Serafini EP, Mandelli J, Zimmermann E, Losquiavo KP. Perinatal transmission of human papilomavirus DNA. Virol J. 2009;6:83.

3. Skoczynski M, Gozdzicka-Jozefiak A, Kwasniewska A. Prevalence of human papillomavirus in spontaneously aborted products of conception. Acta Obstet Gynecol Scand. 2011;90:1402-5.

4. Syrjanen S. Current concepts on human papillomavirus infections in children. APMIS. 2010;118:494-509.

5. Dunne EF, Nielson CM, Stone KM, Markowitz LE, Giuliano AR. Prevalence of HPV infection among men: a systematic review of the literature. J Infect Dis. 2006:194:1044-57.

6. Garolla A, Pizzol D, Foresta C. The role of human papillomavirus on sperm function. Curr Opin Obstet Gynecol. 2011;23:232-7.

7. Foresta C, Pizzol D, Moretti A, Barzon L, Palu G, Garolla A. Clinical and prognostic significance of human papillomavirus DNA in the sperm or exfoliated cells of infertile patients and subjects with risk factors. Fertil Steril. 2010:94:1723-7.

8. Garland SM, Ault KA, Gall SA, Paavonen J, Sings HL, Ciprero KL, Saah A, Marino D, Ryan D, Radley D, Zhou H, Haupt RM, Garner El. Quadrivalent human papillomavirus vaccine phase III investigators: pregnancy and infant outcomes in the clinical trials of a human papillomavirus type 6/11/16/ 18 vaccine: a combined analysis of five randomized controlled trials. Obstet Gynecol. 2009;114(6):1179-88.

9. Smith EM, Parker MA, Rubenstein LM, Haugen TH, Hamsikova E, Turek LP. Evidence for vertical transmission of HPV from mothers to infants. Infect Dis Obstet Gynecol. 2010;2010:326369.

10. Tucker RA, Johnson PR, Reeves WC, Icenogle JP. Using the polymerase chain reaction to genotype human papillomavirus DNAs in samples containing multiple HPVs may produce inaccurate results. J Virol Methods. 1993:43:321-33.

11. Minkoff H, Chervenak FA. Elective primary cesarean delivery. N Engl J Med. 2003;348:946-50

12. Rintala MA, Grenman SE, Puranen MH, Isolauri E, Ekblad U, Kero PO, et al. Transmission of high-risk human papillomavirus (HPV) between parents and infant: a prospective study of HPV in families in Finland. J Clin Microbiol. 2005;43:376-81.
13. Brun-Micaleff E, Coffy A, Rey V, Didelot MN, Combecal J, Doutre S, et al. Cervical cancer screening by cytology and human papillomavirus testing during pregnancy in French women with poor adhesion to regular cervical screening. J Med Virol. 2014;86(3):536-45.

14. Kwon MJ, Roh KH, Park H, Woo HY. Comparison of the Anyplex II HPV28 assay with the hybrid capture 2 assay for the detection of HPV infection. $J$ Clin Virol. 2014;59(4):246-9.

15. Schmitt M, Depuydt C, Benoy I, Bogers J, Antoine J, Pawlita M, VALGENT study group, et al. Viral load of high-risk human papillomaviruses as reliable clinical predictor for the presence of cervical lesions. Cancer Epidemiol Biomarkers Prev. 2013:22(3):406-14

16. Castellsague X, Drudis T, Canadas MP, Gonce A, Ros R, Perez JM, et al. Human papillomavirus (HPV) infection in pregnant women and mother-tochild transmission of genital HPV genotypes: a prospective study in Spain. BMC Infect Dis. 2009:9:74.

17. Bandyopadhyay S, Sen S, Majumdar L, Chatterjee R. Human papillomavirus infection among Indian mothers and their infants. Asian Pac J Cancer Prev. 2003:4:179-84.

18. Lacour DE, Trimble C. Human papillomavirus in infants: transmission, prevalence, and persistence. J Pediatr Adolesc Gynecol. 2012;25(2):93-7.

19. Watts DH, Koutsky LA, Holmes KK, Goldman D, Kuypers J, Kiviat NB, et al. Low risk of perinatal transmission of human papillomavirus: results from a prospective cohort study. Am J Obstet Gynecol. 1998;178:365-73.

20. Smith EM, Ritchie JM, Yankowitz J, Swarnavel S, Wang D, Haugen TH, et al. Human papillomavirus prevalence and types in newborns and parents: concordance and modes of transmission. Sex Transm Dis. 2004;31(1):57-62.

21. Trottier H, Mayrand MH, Coutlée F, Monnier P, Laporte L, Niyibizi J, et al. Human papillomavirus (HPV) perinatal transmission and risk of HPV persistence among children: design, methods and preliminary results of the HERITAGE study. Papillomavirus Research. 2016;2:145-52.

22. Kero K, Rautava J, Syrjanen K, Grenman S, Syrjanen S. Human papillomavirus genotypes in male genitalia and their concordance among pregnant spouses participating in the Finnish family HPV study. J Sex Med. 2011;8: 2522-31

23. Kero K, Rautava J, Syrjänen K, Grenman S, Syrjänen S. Oral mucosa as a reservoir of human papillomavirus: point prevalence, genotype distribution, and incident infections among males in a 7-year prospective study. Eur Urol. 2012;62(6):1063-70

\section{Publisher's Note}

Springer Nature remains neutral with regard to jurisdictional claims in published maps and institutional affiliations.

Submit your next manuscript to BioMed Central and we will help you at every step:

- We accept pre-submission inquiries

- Our selector tool helps you to find the most relevant journal

- We provide round the clock customer support

- Convenient online submission

- Thorough peer review

- Inclusion in PubMed and all major indexing services

- Maximum visibility for your research

Submit your manuscript at www.biomedcentral.com/submit
Biomed Central 